\title{
Does pro-patent policy spur innovation? : A case of software industry in Japan
}

\author{
Masayo Kani and Kazuyuki Motohashi (*) \\ Department of Technology Management for Innovation, University of Tokyo \\ 7-3-1 Hongo Bunkyo-ku Tokyo, 113-8656, Japan \\ e-mail: motohashi@tmi.t.u-tokyo.ac.jp; tel: +81-3-5841-1828
}

\begin{abstract}
In Japan, the software patent system has been reformed and now software has become a patentable subject matter. In this paper, this pro-patent shift on software is surveyed and its impact on software innovation is analyzed. Before the 1990's, inventions related to software could not be patented by themselves, but they could be applied when combined with hardware related inventions. Therefore, integrated electronics firms used to be the major software patent applicants.

However, during the period from the late 1990's to the early 2000's, when software patent reforms were introduced, innovative activities (measuring patent applications) by independent software development firms began.

We use the datasets linking IIP patent database (individual patent datasets by using JPO's publication data) and firm level data from the Survey on Selected Services (software part) by the Japanese Ministry of Economy Trade and Industry. Based on the panel datasets for roughly 6000 firms from 1993 to 2007, we found that patent system reforms in the late 1990's have significant impacts on software firm's patenting activities. It is also found that $\mathrm{R} \& \mathrm{D}$ intensive firms increases its patent application more and a relative importance of large software house, typically a primary contractor at the top of the multi-layered industrial structure, is fading in patenting activities.
\end{abstract}

\section{Introduction}

The Japanese government published the Strategic Framework for Intellectual Property Policy in June 2003. The purpose of this policy is to enhance Japan's industrial competitiveness by promoting the creation, strengthening the protection, and promoting the utilization of intellectual property (IP). In addition, the Basic Law on Intellectual Property was established in November 2003, and led to action plans to promote the creation, dissemination, and effective exploitation of IP to contribute to the development of new industries. Implementation of this action plan involves various related ministries, and is coordinated by the Intellectual Property Policy Headquarters, headed by the Prime Minister.

Since the beginning of the 1990s, Japan's economy has been mired in long period of stagnation. Stimulation of business innovation is vital to breaking out of this confining situation. The Strategic Framework for Intellectual Property aims to encourage innovation through proactive actions plans for stimulating, effective use of intellectual property. Key elements of the Strategic Framework include so-called propatent policies, which involve speeding up patent examination procedures, revising the tort system, and protecting IP in new fields such as biotechnology and information technology (IT).
Against this background, one frequently encounters the argument that the pro-patent policies adopted by the U.S., which had been mired in decreasing competitiveness in the 1980s, provided the driving force behind today's rebirth of American competitiveness. Representative examples of propatent policies advanced in the U.S. in the 1980s include the establishment of the Court of Appeals for the Federal Circuit (CAFC) to specialize in appeals concerning patent infringement, and the extension of patent protections in the biotechnology and software fields. Such extension and strengthening of patent rights is argued to have stimulated business innovation, leading to the enhancement of US competitiveness. In addition, in the U.S., the amount of damage compensation in connection with patent disputes has recently soared. This increase may contribute to the trend towards the strengthening of patent rights as well.

However, even in the U.S., opinions are divided as to whether pro-patent policies to expand and strengthen patent protections have had any visible effects on business innovation. A wide range of factors influence the incentives for research and development (R\&D) investment and new product development by businesses. These factors include the economic condition of the businesses, as well as expanding technological opportunities, and policy factors not related to the IP system (i.e. pharmaceutical safety regulations). Results of most analyses, primarily of U.S. cases, indicate that propatent policies have only marginal effects on business innovation [1],[2],[3]. In addition, one criticism of pro-patent policies lies in the "anti-commons" problem. Taking the pharmaceuticals field as an example, the anti-commons argument states that successive applications of patent protections to genetic innovations results in decreased $R \& D$ efficiency, by increasing the number of patent licenses required in order to conduct such R\&D [4]. Another vital issue concerns the goal of IP rights policies to promote the circulation of technology by providing incentives for business innovation and clarifying rights to established technologies. Granting excessive exclusive rights to specific technologies may impede the circulation of such technology.

This paper empirically investigates the role of software patents in innovations by software companies. Originally, software related invention could be protected by copyright. However, since copyright law ultimately protects expression, not ideas, protection of software under patent law also came under consideration. In the consideration of patent protection for software, issues arose concerning whether software qualifies under the patent law requirement that an invention include technological ideas along the line of natural science theory. Through the early 1990s, software itself, which consisted simply of calculation methods, was not considered to be subject to patent protection. However, software enabling 
the functioning of hardware, such as the Japanese language input system used in word processors, was allowed patent protection together with such hardware. In line with the increase in packaged software not embedded in hardware, in 1997 patent protection was allowed for software recorded on media such as floppy disks. In 2000, software was made eligible for patent protection as software itself, and in 2002 this protection was extended to software that circulates on computer networks.

In order to investigate the impact of software patent reforms, we have constructed the database of Japanese software firms by linking the IIP patent database and firm level data from the Survey on Selected Services (software part), by the Japanese Ministry of Economy, Trade and Industry (METI). These datasets have been used for empirical analysis of innovation activities of software firms since the early 1990's, i.e., before and after pro-patent policy on software in Japan. The next section of this paper surveys a discussion on software patents as well as existing studies in this topic. Section 3 describes the dataset and the trend of patenting activities by software companies. Then, a section for econometrics analysis on software patent and innovation follows. Finally this paper concludes with a summary of findings and policy implications.

\section{Survey of software the patent system and its economic impact}

Granting patent rights for software began in the United States. In 1981, the Supreme Court stated that a mathematical formula, computer program, or digital computer" and a claim is patentable if it is embedded with equipment (Diamond v. Diehr). In 1994, the Court of Appeals for the Federal Circuit (CAFC) ruled in the In Re Alappat case that computer software is patentable per se by using the same nonobviousness and inventive step requirement. As a consequence of this court decision, the United States Patent and Trademark Office (USPTO) issued a comprehensive revision to examine guidelines for computer related inventions, explicitly indicating software as a patentable subject matter. In addition, the CAFC supported the patentability of business method (re State Street Bank) in 1998, which was followed by an explosion of business method patent applications.

In Japan, software became patentable in a similar way. First, the Japan Patent Office (JPO) issued examination guidelines in 1993, stating only computer software coupled with hardware inventions could be patented. In 1997, the JPO decided that storage media containing software could also be regarded as a patentable subject matter. This guideline was amended again in 2000 and software itself (including software provided online without storage media) has been patentable since then. Furthermore, in 2002, patent law was finally amended to designate explicitly "software" as a patentable subject. In terms of business method patents, such patent applications increased sharply in Japan as well after the State Street Bank case, but it was a temporary explosion since the agreement of examination guidelines by the European Patent Office (EPO), JPO and USPTO was only achieved in 2000.
In contrast to such movements, there are some arguments against software patents. It may be difficult to evaluate novelty and inventive steps in software invention. As a result, increasing low quality patents lead to higher probability in patent infringement. There is also a view that increasing the number of software related patents creates a dense patent thicket and does harm to innovation in the IT industry. It was found that a substantial share of patent applications is not for protecting the patent's invention, but for ensuring the flexibility of R\&D in some technology fields [5]. This kind of motivation for patenting further pushes up the number of patent applications and blurs the boundaries between patent claims (as a result of the intangible nature of software), which may lead to increases in potential patent infringement cases and transaction costs in the technology market [6].

On the other hand, there are also views in favor of software patents. There some studies indicating that software patents are relatively higher in their economic value. [8] showed that marginal contribution to the Tobin's Q of a firm is higher for software patents than for other types. In addition, it was found that there is a positive relationship between the survival rate of internet startup companies since the IT bubble burst and the number of software patents [9].

Software related inventions could be patented with hardware, even before system reforms were introduced. Therefore, recent reforms may not have a substantial impact on large electronics firms, who invent software as well as hardware. On the other hand, an impact can be found in purely software companies.

\section{Data description and patenting activities of software companies}

In this paper, we have constructed the datasets by linking the following two types of databases.

- Survey of Selected Service Industry: METI's survey data at establishment level, annually conducted for all establishments in some service area (including software).

- IIP Patent Database: Individual patent database constructed from the JPO's patent publication information [10].

Individual patent data by the IIP patent database is aggregated at the firm level by using applicant name and matched with the establishment level data from the Survey of Selected Service Industry, by using company name and location information (city, town and village level). The number of software establishments in the Survey is about 6,000 for each year, and half of them are single establishment firms. It may be the case that patent application is conducted at establishment level, instead of by whole company. In addition, the address of IP departments in charge of patent application may be different from the address of corporate headquarter. In this case, linkage by using only head-quarter address does not work. Therefore, we have matched the patent data for all establishments, including headquarters and branches of multiple establishment firms.

In this section, a trend of patent application of these software companies is surveyed. First, we have analyzed technology classifications of patents applied by software 
companies. The following technology groups can be found frequently.

- Data processing system for the purpose of management, commerce and financial transactions (including $\mathrm{e}$ commerce and business method): G06F17/60, G06F15/20,21 (version 4)

- Information systems and control inside computer: G06F12/, G06F13/

- Information retrieval and database structure: G06F17/30, G06F15/40 (version 4)

- Program control: G06F9/

- Digital computer in general: G06F15/

- Error detection: G06F11/

In Figure 1, a time trend of these patent applications is displayed. The patent count peaked in 1991 and decreased thereafter, but increased again in 2006. However, it should be noted that the multiple claim system was introduced in 1989 in Japan, and the number of claims per patent is still increasing. The reason why a large number of patent applications are found before software patenting is allowed, is that there are some diversified firms with some manufacturing outputs. As is shown in the previous section, major system changes on software patents can be seen in 1997, 2000 and 2002. The number of patent application increases in 1997 and 2000, but not in 2002. It is difficult to evaluate the impact of such system changes by looking at macro figures.

Figure 1: The number of patent application and its share in total number of applications

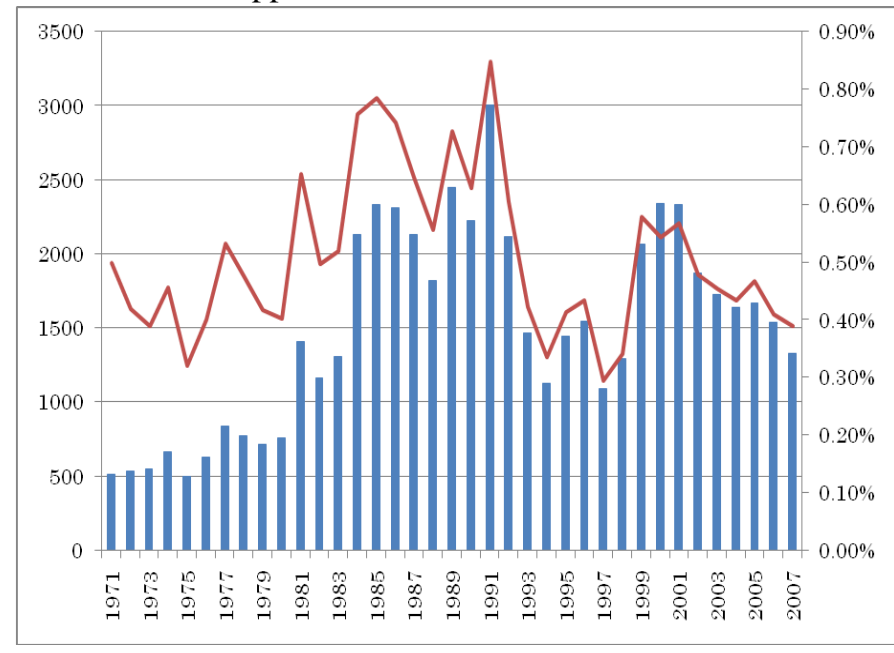

Note: The bar chart shows the number of patent application (right scale), and the line graph presents the share of software patent to total patent applications (left scale)

This kind of macro figures are driven by firms with a large number of patent applications. Therefore, we have evaluated the software patent system change by using a diffusion index (increase $=1$, no change $=0$, decrease $=-1$ ) for each year. The results are indicated in Figure 2. A sharp peak is found in 2000, and no big changes are shown in the early 1990's. Therefore, a large number of patent applications in the early 1990's in Figure 1 is driven by small number of firms with a lot of patents, while the patent number increases around 2000 is made by a large number of firms. The surge in patent increase firms in 2000 can be attributed to changes in patent system, but it may be due to macro economic condition such as IT bubble.

Figure 2: Diffusion indices of patent counts

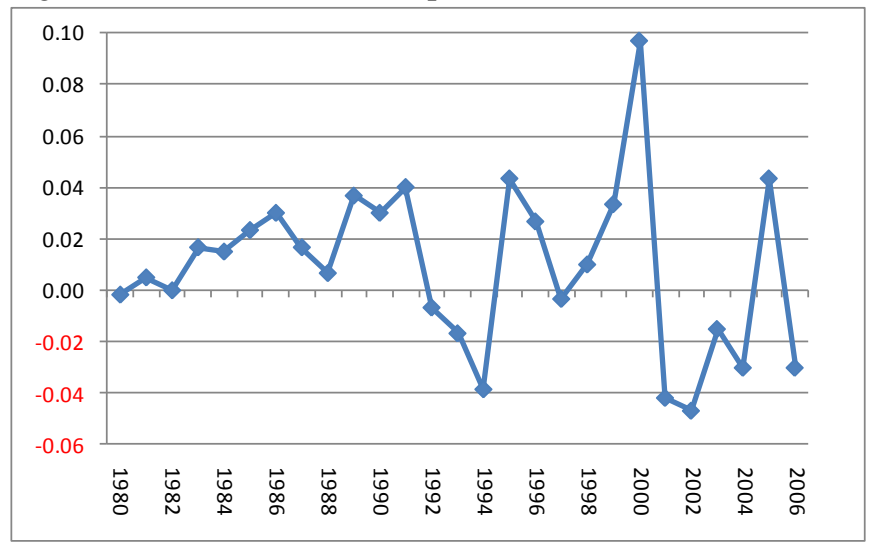

Figure 3, showing the number of firms by year first patent application, suggests that substantial number of firms file a patent in 2000 for the first time. When pro-patent system change is introduced, it becomes easier for a software company to file a patent application. In this case, its incentive for $R \& D$ increases, which may result in a patent application increase. At the same time, there are some software companies, that had never previously patented, which started patenting their inventions. Therefore, we can expect larger numbers of firms to start patenting after the middle 1990's.

Figure 3: Number of firms by first patent application year

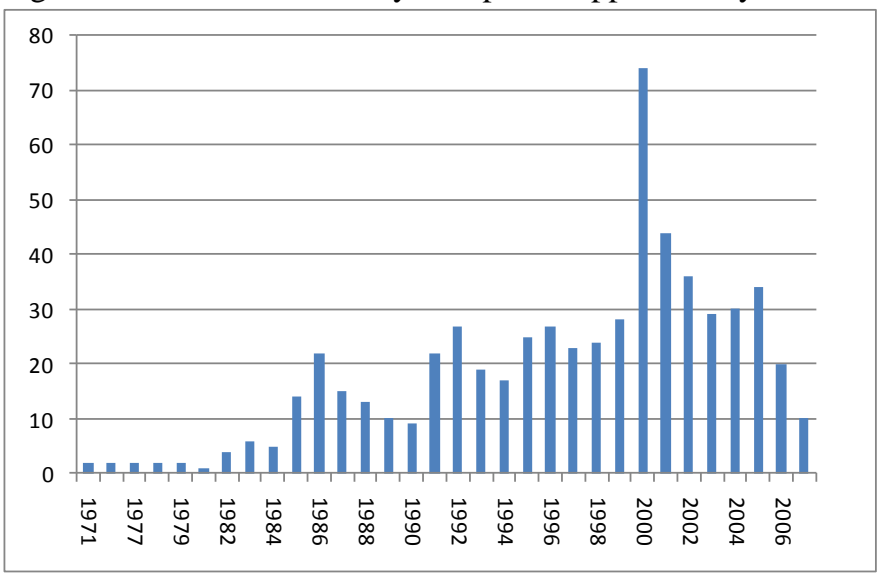

Finally, the Figure 4 shows a trend of the number of patent granted. The number of patent granted increases around 2000, so that increasing number of patent and patent application firms in this period is not just due to IT bubble effect. Rather, patent system reforms lead to greater certainty for potential software patent applicants in terms of patent office's examination criteria, which may influence increasing number of software firms to apply patents. 
Figure 4: Number of granted and non-granted patents

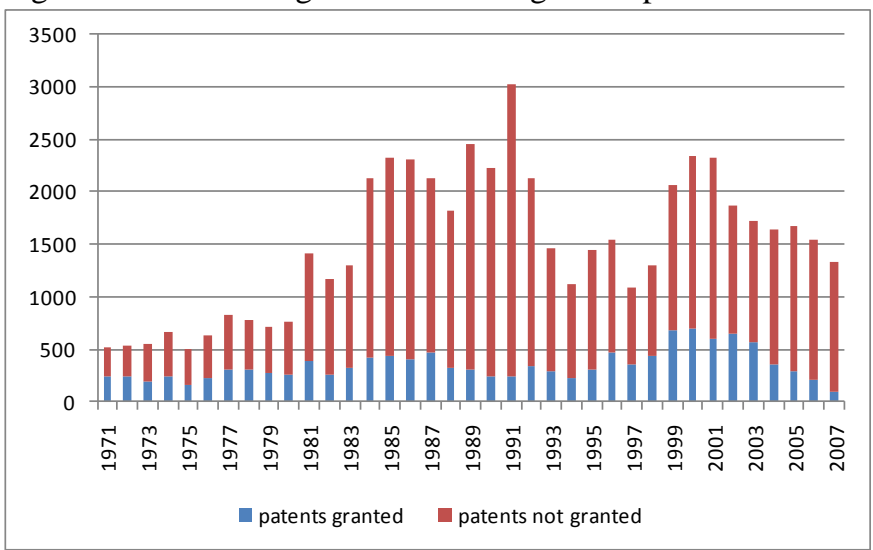

\section{Econometric analysis of patent and software innovation}

In this section, the relationship between patent and innovation for software firms is further investigated by econometric analysis. A key point here is to evaluate the change in patenting behavior of software firms before and after software patent policy changes from the late 1990's. It should be noted that most of our sample firms are diversified software companies, in a sense that they have also non software business activities such as manufacturing. Even before software patent was allowed in Japan, software technology could be patented by combining some hardware technology. Therefore, we have found a substantial number of patent applications before patent system reforms in Japan.

In this section, we use the information of manufacturing output share to differentiate policy change impact from other factors driving changing number of patent applications such as increasing technological opportunity and macro economic environment. We are looking at the changes in relative difference of patent applications by the degree of diversification to manufacturing, before and after policy change period. This difference in difference (DD) estimator allows us to take out a policy impact part from the actual patent counts influenced by various other factors as well.

We have conducted two types of economic analysis, by using a dummy variable whether a firm applies a patent or not and $\log$ of number of patent application plus 1 as a dependent variables. The key independent variable is a policy change variable, where we split a whole sample into the period before 1999 and after 2000 and use a dummy for after 2000 samples as after policy change period. The degree of diversification to manufacturing is measured by the share of manufacturing output at firm. In addition, we include the cross term of a dummy after 2000 and the share of manufacturing output, as a DD estimator.

In addition, we include a $R \& D$ related variable in our empirical model. The Survey of Selected Services by METI provides detail information on occupation mix of firm's employees. A software related employees are broken down into (1) R\&D staffs, (2) systems engineers (SE), (3) programmer and (4) other administrative and supporting staffs. A total number of employees are also available, so that we use the share of R\&D staffs in software business to capture
R\&D intensity. A cross term of this variable with a dummy for policy change is also used as a regressor to see whether $R \& D$ intensive firms increase patent application after pro-patent policy change. We also use the share of software employee to total as a control variable.

Another type of variables used in this study is related to an industrial organization of Japanese software industry, which can be characterized as a "multi-layered subcontracting system" [11]. A subcontracting structure is headed by a large system integrator and multiple subcontracting software companies support such a structure. In many cases, subcontracting firms are small and lack the technological capability of independent businesses. It is found that the share of custom made software is significantly larger in Japan than the United States, where pre-package software is more popular [12]. Relatively large demand for custom made software may explain the system depending on subcontracting structure in Japanese software industry. Pro-patent reform may help small subcontracting firms to become independent from this multilayered structure, by protecting its key technology by patent. [2] illustrates US pro-patent reforms in 1980's leads to growing number of fab-less semiconductor design companies in a similar vein.

In order to identify each firm's "location" in this multilayered system, we use two indicators, i.e. (1) the share of outsourced software sales and (2) the share of outsourcing software in its operation cost. The first indicator indicates the degree of subcontractor status (lower layer of the system), while second indicator shows the degree of primary contractor status (upper layer of the system). We also take a cross term of them. The large this cross term is, the more likely a firm is involved with subcontracting and subcontracted. Hence, this cross terms infers the degree of secondary contractor status (middle layer of the system). We take a cross term of these indicators with a dummy for policy change to show how patenting behavior is different before and after depending on the layer of the system.

Finally we include the following controlling variables

Log of firm's employee size

- Dummies for headquarter, as well as branch of multiple establishment firm (single establishment firm as a base)

- Year dummies

Table 1 and Table 2 show the results of probit model of a dummy for patent or not and tobit model of log of number of patent application plus one, respectively, and both of them are consistent each other. As we expected, the coefficients to share of manufacturing is positive and statistically significant for all models. In addition, negative and statistically coefficients to the cross term of manufacturing share and policy change shows that for a firm with higher manufacturing output share, the likelihood of filing patent and the number of patent applications is relatively smaller for the period after 2000's. Hence, we have expected results by this DD estimator, in a sense that software patent reform from the late 1990's may contribute to patent applications more for a firms with higher software output. 
Table 1: Regression results (Dependent variable=With patent or not, Probit Model)

\begin{tabular}{|c|c|c|c|}
\hline & (1) & (2) & (3) \\
\hline$\overline{l o g(\text { EMP })}$ & $\begin{array}{c}0.178 \\
(24.30)^{* *}\end{array}$ & $\begin{array}{c}0.178 \\
(24.29)^{* *}\end{array}$ & $\begin{array}{c}0.181 \\
(23.99)^{* *}\end{array}$ \\
\hline Share of software employees & $\begin{array}{l}-0.040 \\
(1.79)+\end{array}$ & $\begin{array}{l}-0.040 \\
(1.79)+\end{array}$ & $\begin{array}{l}0.010 \\
(0.48)\end{array}$ \\
\hline $\begin{array}{l}\text { Share of R\&D employees in software business } \\
\text { (RDEMP) }\end{array}$ & $\begin{array}{l}0.077 \\
(1.52)\end{array}$ & $\begin{array}{r}-0.088 \\
(0.79)\end{array}$ & $\begin{array}{l}0.015 \\
(0.30)\end{array}$ \\
\hline RDEMP* Dummy for policy change (2000-) & & $\begin{array}{c}0.211 \\
(1.69)+\end{array}$ & \\
\hline Share of manufacturing outputs (MAN) & $\begin{array}{c}0.632 \\
(5.70)^{* *}\end{array}$ & $\begin{array}{c}0.639 \\
(5.75)^{* *}\end{array}$ & $\begin{array}{c}0.507 \\
(4.30)^{* * *}\end{array}$ \\
\hline MAN* Dummy for policy change (2000-) & $\begin{array}{l}-0.682 \\
(6.08)^{* *}\end{array}$ & $\begin{array}{l}-0.688 \\
(6.13)^{* *}\end{array}$ & $\begin{array}{l}-0.560 \\
(4.70)^{* * *}\end{array}$ \\
\hline $\begin{array}{l}\text { Share of outsourcing of software (A) } \\
\text { (Degree of subcontractor) }\end{array}$ & & & $\begin{array}{l}-0.293 \\
(2.77)^{* *}\end{array}$ \\
\hline $\begin{array}{l}\text { Share of sales to software house (B) } \\
\text { (Degree of primary contractor) }\end{array}$ & & & $\begin{array}{c}0.280 \\
(1.75)+\end{array}$ \\
\hline $\begin{array}{l}\text { Cross term of A and B ( C) } \\
\text { (Degree of secondary contractor) }\end{array}$ & & & $\begin{array}{r}-0.450 \\
(0.94)\end{array}$ \\
\hline $\mathrm{A}^{*}$ Dummy for policy change (2000-) & & & $\begin{array}{r}-0.112 \\
(0.98) \\
\end{array}$ \\
\hline B* Dummy for policy change (2000-) & & & $\begin{array}{l}-0.375 \\
(2.20)^{*}\end{array}$ \\
\hline $\mathrm{C}^{*}$ Dummy for policy change (2000-) & & & $\begin{array}{l}0.696 \\
(1.39)\end{array}$ \\
\hline $\begin{array}{l}\text { Dummy for headquarter of multiple est. firm } \\
\text { (Single est. firm as a base) }\end{array}$ & $\begin{array}{c}0.20 \\
(9.34)^{* *}\end{array}$ & $\begin{array}{c}0.20 \\
(9.35)^{* * *}\end{array}$ & $\begin{array}{c}0.18 \\
(8.28)^{* * *}\end{array}$ \\
\hline $\begin{array}{l}\text { Dummy for branch of multiple est. firm } \\
\text { (Single est. firm as a base) }\end{array}$ & $\begin{array}{c}(0.68) \\
(21.83)^{* *}\end{array}$ & $\begin{array}{c}(0.68) \\
(21.84)^{* *}\end{array}$ & $\begin{array}{c}(0.70) \\
(20.59)^{* *}\end{array}$ \\
\hline Constant & $\begin{array}{c}-2.202 \\
(60.24)^{* *}\end{array}$ & $\begin{array}{c}-2.203 \\
(60.25)^{* *}\end{array}$ & $\begin{array}{c}-2.120 \\
(57.08)^{* *}\end{array}$ \\
\hline Year Dummy & YES & YES & YES \\
\hline \# of Observations & 56615 & 56615 & 54583 \\
\hline
\end{tabular}

In model (2) of Table 1 and Table 2, positive and statistically significant coefficients are found for the cross term of RDEMP and policy change, which implies that a higher R\&D intensity firm tends to apply more patent after 2000. This may be due to the fact that patent system can be used by $R \& D$ intensive software firms more easily after software patent reforms. In terms of the firm's "location" in the multi-layered system, we have found that a primary contractor tends to apply more patent, while a subcontractor applies less. However, as we can the results in cross terms, higher patent propensity for a primary contractor decreases over time. As is shown in Figure 3, a substantial number of firms first applied patent after 2000. Patent system reforms for software may encourage small software firm's innovative activities, while the relative importance of large firms in patenting activities decreases.
Table 2: Regression results (Dependent variable $=\log$ (Number of patent application+1): Tobit Model)

\begin{tabular}{|c|c|c|c|}
\hline & (1) & $(2)$ & (3) \\
\hline $\log (\mathrm{EMP})$ & $\begin{array}{c}0.750 \\
(27.88)^{* *} \\
\end{array}$ & $\begin{array}{c}0.750 \\
(27.87)^{* * *} \\
\end{array}$ & $\begin{array}{c}0.751 \\
(27.64) * * \\
\end{array}$ \\
\hline Share of software employees & $\begin{array}{r}-0.128 \\
(1.64) \\
\end{array}$ & $\begin{array}{r}-0.128 \\
(1.64) \\
\end{array}$ & $\begin{array}{l}0.053 \\
(0.76) \\
\end{array}$ \\
\hline $\begin{array}{l}\text { Share of R\&D employees in software business } \\
\text { (RDEMP) }\end{array}$ & $\begin{array}{c}0.499 \\
(2.85)^{* *}\end{array}$ & $\begin{array}{r}-0.101 \\
(0.26) \\
\end{array}$ & $\begin{array}{l}0.278 \\
(1.60) \\
\end{array}$ \\
\hline RDEMP* Dummy for policy change (2000-) & & $\begin{array}{c}0.767 \\
(1.78)+ \\
\end{array}$ & \\
\hline Share of manufacturing outputs (MAN) & $\begin{array}{c}2.451 \\
(6.48)^{* *} \\
\end{array}$ & $\begin{array}{c}2.475 \\
(6.53)^{* *} \\
\end{array}$ & $\begin{array}{l}1.934 \\
(4.91)^{* * *}\end{array}$ \\
\hline MAN* Dummy for policy change (2000-) & $\begin{array}{l}-2.613 \\
(6.83)^{* *} \\
\end{array}$ & $\begin{array}{l}-2.637 \\
(6.88)^{* *} \\
\end{array}$ & $\begin{array}{l}-2.106 \\
(5.28)^{* *} \\
\end{array}$ \\
\hline $\begin{array}{l}\text { Share of outsourcing of software (A) } \\
\text { (Degree of subcontractor) }\end{array}$ & & & $\begin{array}{l}-0.977 \\
(2.67)^{* *}\end{array}$ \\
\hline $\begin{array}{l}\text { Share of sales to software house (B) } \\
\text { (Degree of primary contractor) }\end{array}$ & & & $\begin{array}{c}0.970 \\
(1.78)+ \\
\end{array}$ \\
\hline $\begin{array}{l}\text { Cross term of A and B ( C) } \\
\text { (Degree of secondary contractor) }\end{array}$ & & & $\begin{array}{r}-1.953 \\
(1.17) \\
\end{array}$ \\
\hline A* Dummy for policy change (2000-) & & & $\begin{array}{r}-0.438 \\
(1.10) \\
\end{array}$ \\
\hline B* Dummy for policy change (2000-) & & & $\begin{array}{l}-1.328 \\
(2.27)^{*}\end{array}$ \\
\hline$C^{*}$ Dummy for policy change (2000-) & & & $\begin{array}{l}2.619 \\
(1.50) \\
\end{array}$ \\
\hline $\begin{array}{l}\text { Dummy for headquarter of multiple est. firm } \\
\text { (Single est. firm as a base) }\end{array}$ & $\begin{array}{c}0.64 \\
(8.59)^{* * *} \\
\end{array}$ & $\begin{array}{c}0.64 \\
(8.60)^{* *} \\
\end{array}$ & $\begin{array}{c}0.56 \\
(7.51)^{* * *} \\
\end{array}$ \\
\hline $\begin{array}{l}\text { Dummy for branch of multiple est. firm } \\
\text { (Single est. firm as a base) }\end{array}$ & $\begin{array}{c}(2.38) \\
(20.83)^{* *}\end{array}$ & $\begin{array}{c}(2.38) \\
(20.83)^{* *}\end{array}$ & $\begin{array}{c}(2.40) \\
(19.82)^{* *}\end{array}$ \\
\hline Constant & $\begin{array}{c}-8.303 \\
(47.27)^{* *} \\
\end{array}$ & $\begin{array}{c}-8.307 \\
(47.28)^{* * *}\end{array}$ & $\begin{array}{c}-7.849 \\
(45.77)^{* *} \\
\end{array}$ \\
\hline Year Dummy & YES & YES & YES \\
\hline \# of Observations & 56615 & 56615 & 54583 \\
\hline
\end{tabular}

\section{Conclusion}

In Japan, the software patent system has been reformed and software is now a patentable subject matter. In this paper, this pro-patent shift on software was surveyed and its impact on software innovation was analyzed. Before the 1990's, inventions related to software could not be patented by themselves, but they could be applied by being combined with hardware related inventions. Therefore, integrated electronics firms used to be major software patent applicants. However, during the period of the late 1990's and early 2000's, when software patent reforms were introduced, innovative activities (measuring patent applications) by independent software development firms began.

We use the datasets linking IIP patent database (individual patent datasets by using JPO's publication data) and firm level data from the Survey on Selected Services (software part) (METI). Based on the panel datasets for roughly 6000 firms from 1993 to 2007, we found that patent system reforms in the late 1990's have significant impacts on software firm's patenting activities. It is also found that $\mathrm{R} \& \mathrm{D}$ intensive firms increases its patent application more and a relative importance of large software house, typically a primary contractor at the top of the multi-layered industrial structure, is fading in patenting activities .

The competitive standing of the software industry in Japan is notably low in terms of trade statistics, and its productivity 
is considered low in comparison to that of Europe and the United States [13]. This may be explained by the fact that labor intensive custom made software plays a dominant role in the Japanese software industry. In addition, the multi layered subcontracting system makes the situation worse, in the sense that small-scale subcontracting software firms lower the aggregated productivity level of the software industry. In this sense, pro-patent reform on software invention may induce independent strategies by in-house technological capabilities, and contribute to competitiveness and productivity in the Japanese software industry.

\section{Acknowledgments}

This paper is prepared for a research project by the Institute of Intellectual Property (IIP), Tokyo Japan. Authors thank for IIP for its financial assistance and arrangement of dataset used in this paper. Authors thank also for anonymous reviewers at ITMC 2011 conference for helpful comments.

\section{References}

1. Kortum, S. and J. Lerner (1999), What is behind the recent surge in patenting?, Research Policy, vol. 28, pp. $1-22$.

2. Hall, B. and R. Ziedonis (2001), An Empirical Study of Patenting in the US Semiconductor Industry, 1979-1995, Rand Journal of Economics, Vol. 32, No. 1 pp. 101-128.

3. Lerner, J. (2002), Patent Protection and Innovation over 150 Years, NBER Working Paper Series, No. 8977.

4. Heller, M. A. and R. S. Eisenberg (1998), Can Patents Deter Innovation? The Anti-commons in Biomedical Research, Science, vol. 280 no. 5364, 698-701

5. Graham, S. and D. Mowery (2003), Intellectual Property Protection in the U.S. Software Industry, in Patents in the Knowledge Based Economy, National Academy of Science, Washington D.C. USA.

6. Branstetter, L. and M. Sakakibara (2001), Do Stronger Patents Induce More Innovation? Evidence from the 1988 Japanese Patent Law Reforms. RAND Journal of Economics, 32, 1, 77-100.

7. Cockburn, I., MacGarvie, M. (2009), Patents, Thickets and the Financing of Early-Stage Firms: Evidence from the Software Industry." Journal of Economics and Management Strategy, 18(3), 729-773

8. Hall, B. and M. MacGarvie (2006), The Private Value of Software Patent, NBER Working Paper \#12195.

9. Cockburn, I. and S. Wagner (2007), Patents and the Survival of Internet Related IPOs, NBER Working Paper \#13146

10. Goto, A., and K. Motohashi (2007), Construction of a Japanese Patent Database and a first look at Japanese patenting activities, Research Policy, Vol. 36, Issue 9, pp. 1431-1442.

11. Minetaki, K. and K. Motohashi, (2009), Subcontracting Structure and Productivity in the Japanese Software Industry, The Review of Socionetwork Strategies 3, 51-65

12. Jorgenson D. W. and K. Motohashi (1995), Information technology and the Japanese economy, Journal of the Japanese and International Economies 19(4), 460-481
13. Imai, K. and F. Ishino (1991), Software in Japan, Business Review, 41-1, pp.1-18, Toyokeizai Shinposha (in Japanese). 